\title{
Benthic macrofauna and the limnological parameters of a first-order stream in Atlantic Forest of Brazilian Northeast
}

\author{
Macrofauna bentônica e as características limnológicas de um riacho de \\ primeira ordem da Mata Atlântica do Nordeste Brasileiro
}

Janaina Câmara Siqueira da Cunha ${ }^{1}$, Renato Galindo de Barros Filho ${ }^{2}$, Rafael Pereira da Silva ${ }^{2}$, Iris Gabrielly Arruda dos Santos ${ }^{1}$ and Gilberto Gonçalves Rodrigues ${ }^{3}$
'Programa de Pós-graduaçáo em Biologia Animal - PPGBA, Universidade Federal de Pernambuco - UFPE, Av. Prof. Moraes Rego, 1235, Cidade Universitária, CEP 50670-901, Recife, PE, Brazil e-mail: janainacsc@gmail.com; iris.arrudasantos@gmail.com
${ }^{2}$ Centro de Ciências Biológicas - CCB, Universidade Federal de Pernambuco - UFPE, Av. Prof. Moraes Rego, 1235, Cidade Universitária, CEP 50670-901, Recife, PE, Brazil e-mail: renatogallindo@gmail.com; rafaelpsilvape@gmail.com
${ }^{3}$ Departamento de Zoologia, Centro de Ciências Biológicas - CCB, Universidade Federal de Pernambuco - UFPE, Av. Prof. Moraes Rego, 1235, Cidade Universitária, CEP 50670-901, Recife, PE, Brazil e-mail: gilberto.rodrigues@ufpe.br

\begin{abstract}
Aim: The present study aimed to elucidate if the water physical and chemical parameters from a first order stream of Biological Reserve of Saltinho from south Pernambuco induces in the distribution and abundance of benthic macroinvertebrates. Methods: Both limnological parameters ( $\mathrm{pH}$-value, electrical conductivity, water temperature, turbidity, salinity and dissolved oxygen) and structural variables of aquatic habitat (substrate, food availability and flow velocity) influence the macroinvertebrates community structure. The creek is very small, with an approximate width of 1-3 m and a depth of $0.5 \mathrm{~m}$. It was used a Surber sampler $(100 \mu \mathrm{m})$ in three stretch of the creek, each one with two sampling units (s.u.) totaling six s.u. distant $50 \mathrm{~m}$, with a sampling effort of five minutes per s.u.. The measurer multiparameter was used in order to obtain the water analysis (limnological parameters). Results: From 11 taxa of macroinvertebrates found no significant correlation $(\mathrm{p}<0.05)$ was presented with $\mathrm{pH}$-value, water temperature and salinity, but some taxa showed with electrical conductivity (EC), turbidity (TD) and dissolved oxygen (DO). Hemiptera abundance increases with decreasing DO; Ostracoda abundance increases with increasing EC and TD and the decrease in DO; and Trichoptera abundance increases with the decrease in EC and TD and the increase in DO. The stretches exhibited similarity in relation to the richness and abundance of macroinvertebrates and limnological parameters. The macroinvertebrates distribution in the stream not showed the same pattern, grouping s.u. of different stretch, because the habitat structural variables influenced the distribution. Conclusions: Therefore, the macroinvertebrates community varies according to abiotic factors in different limnological and structural parameters. This study is the first record of a work that associates benthic fauna and abiotic parameters at the Atlantic forest of Pernambuco.
\end{abstract}

Keywords: macroinvertebrates, abiotic variables, stream, Atlantic forest, benthic fauna.

Resumo: Objetivo: $\mathrm{O}$ presente trabalho teve por objetivo elucidar se as variáveis físicas e químicas da água, de um riacho de primeira ordem da Reserva Biológica de Saltinho do sul de Pernambuco atuam na distribuição e abundância dos macroinvertebrados bentônicos. Métodos: Sabe-se que tanto as variáveis limnológicas ( $\mathrm{pH}$, condutividade, temperatura, turbidez, salinidade e oxigênio dissolvido) quanto as variáveis estruturais do habitat aquático (substrato, disponibilidade de alimento e velocidade do fluxo) influenciam na estrutura da comunidade de macroinvertebrados. O riacho é muito pequeno com largura aproximada de $1-3 \mathrm{~m}$ e profundidade de $0,5 \mathrm{~m}$. Foi utilizado um amostrador tipo Surber $(100 \mu \mathrm{m})$ em três trechos do riacho, cada um com duas unidades amostrais (u.a.) totalizando seis u.a. distantes $50 \mathrm{~m}$, com um esforço amostral de cinco minutos por u.a.; as variáveis da água foram coletadas com o auxílio do medidor multiparâmetro de qualidade da água. Resultados: Dos 11 táxons encontrados nenhum exibiu correlação significativa $(\mathrm{p}<0,05) \mathrm{com} \mathrm{pH}$, temperatura e salinidade, mas alguns táxons apresentaram 
com as outras variáveis. Hemiptera aumenta a abundância com o decréscimo de oxigênio dissolvido (OD); Ostracoda aumenta com o acréscimo da condutividade elétrica (CE), turbidez (TB) e o decréscimo do OD; e Trichoptera aumenta com a diminuição da CE e $\mathrm{TB}$ e com o aumento do $\mathrm{OD}$. Cada trecho exibiu similaridade em relação à riqueza e abundância dos táxons e às variáveis limnológicas. A distribuição dos táxons no riacho não apresentou o mesmo padrão, agrupando as u.a de trechos distintos, devido às variáveis estruturais do habitat. Conclusóes: Assim, a comunidade de macroinvertebrados variou de acordo com as variáveis abióticas nos diferentes parâmetros estruturais e limnológicos. Este estudo é o primeiro registro de um trabalho associando fauna bentônica e variáveis abióticas na mata atlântica em Pernambuco.

Palavras-chave: macroinvertebrados, variáveis abióticas, riacho, Mata Atlântica, fauna bentônica.

\section{Introduction}

The aquatic macroinvertebrates have great species diversity and several ways of life. They can inhabit from puddles to rivers and are associated with different substrates (Rosenberg and Resh, 1993; Barbola et al., 2011). Their use in aquatic environmental impact assessments becomes frequent due to the great potential bioindicator and can be classified in three main groups (sensitive, tolerant or resistant) related to tolerance of adverse conditions (Goulart and Callisto, 2003; Holt and Miller, 2010). Therefore, they are considered important for the structure and functioning of aquatic ecosystems and their composition may be related to abiotic conditions influencing the structuring and distribution of individuals (Ribeiro and Uieda, 2005; Silva and Henry, 2013).

Thus, natural and anthropogenic factors or process generate patterns in spatial and temporal scales, creating a relationship with community structure that can be influenced by ecosystem type and organism group (Wu and Loucks, 1995). The macroinvertebrate community may differ according to structural variables (substrate composition, food availability and flow velocity) in a small scale or can result of water limnological differences in a large scale (Kikuchi and Uieda, 1998; Melo, 2009). Moreover, abiotic variables may be divided in macro or meso spatial scale in which mesoscale can be structural and limnological with hierarchical relationship between these scales influencing organisms (Vilella et al., 2004; Kubíková et al., 2012).

According to the River Continuum Concept, physical factors are necessary for understanding the dynamics and biological strategies of a river system, in which the use by group of macroinvertebrate functional feeding can be regulated by fluvial geomorphologic process (Vannote et al., 1980). Frissell et al. (1986) defined that in order to an organism occur in a particular habitat it must go through numerous hierarchical filters, which are ecological barriers to the persistence of individual, where the habitat and communities are diverse within stream patch.

So, we sought to elucidate if the physical and chemical parameters of the water of a first order stream influence the abundance and distribution of benthic macroinvertebrates in large group level. Thereby, we tested the hypothesis that aquatic macroinvertebrate community presents changes in its structure according to the abiotic variables.

\section{Material and Methods}

The stream Saltinho is situated into the protected area - Biological Reserve of Saltinho $\left(08^{\circ} 44^{\prime} 13^{\prime \prime}\right.$ and $08^{\circ} 43^{\prime} 09^{\prime \prime} \mathrm{S} / 35^{\circ} 10^{\prime} 11^{\prime \prime}$ and $35^{\circ} 11^{\prime} 02^{\prime \prime}$ W) localized in Tamandare city - Pernambuco. The watershed of the stream has approximately 22.634 ha and 475 ha in the protected area with two supply reservoirs for Tamandare, its source is outside the biological reserve area and its main flow direction is northwestsouthwest flowing into the River Mamucabas (Brasil, 2003).

The samples were collected during rainy season on May, 2013, between 9 a.m. and 4 p.m. in the stream Saltinho, that May to July are the rainiest months in this region. Sampling occurred in three stretches of the stream, divided into three blocks with $150 \mathrm{~m}$ (A, B and C) it was used two sampling units (s.u.) for each stretch distant $50 \mathrm{~m}$ from each other with a sampling effort of five minutes by s.u (Figure 1). Each stretch has 1 to $3 \mathrm{~m}$ of width with depth about $0.5 \mathrm{~m}$. The cover of stream is forested with native species but we found some exotic palm (Elaeis guineensis) and sugar cane (Saccharum officinarum). The substratum is formed mainly by sand-clay and stones. The litter is accumulated in some parts of stream. The creek exhibits high heterogeneity of microhabitats with chutes, waterfalls and backwater area. There are 
some differences between the three blocks sampled in the Saltinho stream (Table 1).

For the collection of individuals we used a manual Surber sampler $\left(30 \mathrm{~cm}^{2}\right.$, open mesh of $\left.100 \mu \mathrm{m}\right)$ and water physical and chemical parameters ( $\mathrm{pH}$-value, salinity, electrical conductivity, water temperature, turbidity and dissolved oxygen) were collected with help of the multi-parameter Hanna HI 9828. The individuals were identified to lowest taxonomic level possible using specific identification keys (Costa et al., 2006; Fernández and Domingues, 2001; Mugnai et al., 2010), preserved in 70\% alcohol and deposited in the collection of the Laboratory of Assessment, Recovery and Restoration of Aquatic Ecosystems - ARRE ÁGUA/UFPE.

For data analysis we used linear correlation with a significance level (p) less than 0.05 and hierarchical clustering of cases (complete linkage) by Euclidean distance, through Statistica ${ }^{\mathrm{TM}}$ 7.0, and values were standardized. These tests were realized to check the existence of a relationship between macroinvertebrates and abiotic variables, in addition to verify how the s.u. is grouped from the macroinvertebrates richness and abundance with limnological parameters.

\section{Results}

A total of 175 individuals $(\mathrm{N}=6)$ were collected in stream Saltinho, belonging to 11 macroinvertebrates (Acari, Amphipoda, Chironomidae, Coleoptera, Ephemeroptera, Gastropoda, Hemiptera, Odonata, Oligochaeta, Ostracoda and Trichoptera). Arthropoda presented almost total individuals (99\%) and the Insecta was the most prominent with six orders. Chironomidae-Diptera represented $46 \%$ of the total abundance, followed by Ostracoda (18\%) and Coleoptera (15\%) (Table 2).

The water physical and chemical parameters not showed significant difference of the six units, because the salinity had similar values in all s.u. It was excluded from the linear correlation analysis (Table 3).

The total abundance of macroinvertebrates presented correlation positive $(0.8119 ; \mathrm{p}=0.041)$

Table 1. Characteristics of the three blocks sampled at the Saltinho stream during the rainy season in May, 2013 at the Biological Reserve of Saltinho, Tamandare city - Pernambuco, Brazil. BD = Boulders; CL = Clay; PB = Pebbles; $\mathrm{SN}=$ Sand.

\begin{tabular}{cccccc}
\hline \multirow{2}{*}{ Blocks } & \multirow{2}{*}{ Substratum } & Average & Variation of water & Average height of & Average widht \\
\cline { 3 - 6 } & & depth $(\mathbf{c m})$ & column $(\mathbf{c m})$ & ravine $(\mathbf{c m})$ & $(\mathbf{c m})$ \\
\hline $\mathrm{A}$ & $\mathrm{CL}$ and $\mathrm{SN}$ & $30.83 \pm 4.95$ & $0.91 \pm 0.58$ & $48.60 \pm 22.21$ & $167.16 \pm 86.40$ \\
$\mathrm{~B}$ & $\mathrm{~PB}$ and $\mathrm{BD}$ & $10.50 \pm 5.00$ & $0.66 \pm 0.25$ & $88.83 \pm 34.08$ & $217.83 \pm 47.49$ \\
$\mathrm{C}$ & $\mathrm{CL}$ and SN & $23.00 \pm 5.51$ & $0.83 \pm 0.25$ & $124.16 \pm 15.84$ & $220.83 \pm 63.67$ \\
\hline
\end{tabular}

Table 2. Macroinvertebrates abundance collected in six sampling units during rainy season (May, 2013) at protected area - Biological Reserve of Saltinho, Tamandare city - Pernambuco, Brazil.

\begin{tabular}{|c|c|c|c|c|c|c|c|}
\hline \multirow{2}{*}{ Taxa } & \multicolumn{6}{|c|}{ Sampling Units } & \multirow{2}{*}{ Total } \\
\hline & 1 & 2 & 3 & 4 & 5 & 6 & \\
\hline \multicolumn{8}{|l|}{ Phylum Mollusca } \\
\hline Class Gastropoda & 1 & 0 & 0 & 0 & 0 & 0 & 1 \\
\hline \multicolumn{8}{|l|}{ Phylum Annelida } \\
\hline Class Oligochaeta & 1 & 0 & 0 & 0 & 0 & 0 & 1 \\
\hline \multicolumn{8}{|l|}{ Phylum Arthropoda } \\
\hline \multicolumn{8}{|l|}{ Class Arachnida } \\
\hline Order Acari & 6 & 4 & 1 & 4 & 3 & 0 & 18 \\
\hline Class Ostracoda & 11 & 13 & 2 & 2 & 2 & 1 & 31 \\
\hline \multicolumn{8}{|l|}{ Class Malacostraca } \\
\hline Order Amphipoda & 0 & 0 & 1 & 0 & 0 & 0 & 1 \\
\hline \multicolumn{8}{|l|}{ Class Insecta } \\
\hline Order Ephemeroptera & 1 & 0 & 0 & 2 & 0 & 0 & 3 \\
\hline Order Odonata & 1 & 0 & 0 & 0 & 3 & 1 & 5 \\
\hline Order Hemiptera & 0 & 4 & 0 & 0 & 0 & 0 & 4 \\
\hline Order Coleoptera & 8 & 1 & 4 & 3 & 2 & 7 & 25 \\
\hline \multicolumn{8}{|l|}{ Order Diptera } \\
\hline Family Chironomidae & 3 & 8 & 20 & 18 & 12 & 19 & 80 \\
\hline Order Trichoptera & 0 & 0 & 1 & 1 & 3 & 1 & 6 \\
\hline Total & 32 & 30 & 29 & 30 & 25 & 29 & 175 \\
\hline
\end{tabular}


Table 3. Abiotic variables values collected with measurer multi-parameter in six sampling units, it occurs during rainy season on the period of May, 2013 at Biological Reserve of Saltinho, Tamandare city - Pernambuco, Brazil.

\begin{tabular}{lcccccc}
\hline \multirow{2}{*}{ Parameters } & \multicolumn{7}{c}{ Sampling Units } \\
\cline { 2 - 7 } & $\mathbf{1}$ & $\mathbf{2}$ & $\mathbf{3}$ & $\mathbf{4}$ & $\mathbf{5}$ & $\mathbf{6}$ \\
\hline pH-value & 6.08 & 6.24 & 6.20 & 5.96 & 6.07 & 5.88 \\
Water temperature $\left({ }^{\circ} \mathrm{C}\right)$ & 24.77 & 24.89 & 24.41 & 24.64 & 25.93 & 25.93 \\
Electrical conductivity $(\mu \mathrm{s} / \mathrm{cm})$ & 70 & 72 & 63 & 64 & 61 & 61 \\
Turbidity $(\mathrm{NTU})$ & 35 & 36 & 31 & 32 & 31 & 30 \\
Salinity $(\mathrm{mg} / \mathrm{L})$ & 0.03 & 0.03 & 0.03 & 0.03 & 0.03 & 0.03 \\
Dissolved oxygen $(\mathrm{mg} / \mathrm{L})$ & 5.12 & 4.77 & 5.72 & 5.57 & 5.63 & 5.54 \\
\hline
\end{tabular}

only with electrical conductivity. The taxa richness of all s.u. not correlated with any abiotic variables. In the linear correlation between macroinvertebrates and limnological parameters, Hemiptera, Ostracoda and Trichoptera were significantly correlated $(\mathrm{p}<0.05)$. Hemiptera showed negative correlation $(-0.8378 ; \mathrm{p}=0.037)$ with dissolved oxygen (DO) that increases their abundance with DO decreasing. While Ostracoda demonstrated positive correlation with electrical conductivity (EC) $(0.9728 ; \mathrm{p}=0.001)$ and turbidity (TD) $(0.9846 ; \mathrm{p}=0)$, increasing their numbers proportionately to these variables and disproportionately with DO, it presents a negative correlation $(-0.9167 ; \mathrm{p}=0.010)$. And lastly Trichoptera that showed opposite Ostracoda with a negative correlation with EC $(-0.8955 ; \mathrm{p}=0.016)$ and TD $(-0.8163 ; \mathrm{p}=0.048)$ and positive with DO (0.8124; $\mathrm{p}=0.049)$.

From the cluster analysis of cases (s.u.), using as variables the macroinvertebrates richness and abundance and limnological parameters, it was found that the s.u. of each stretch are grouped separately that showed the similarity expected by stretch (Figure 2). Performing a cut on the distance between 0.14 and 0.16 were separated three groups with the s.u. of each stretch grouping.

Sampling units are grouped differently independently of the stretches, when are included the 11 taxa separately and the limnological parameters (Figure 3). From the cut between 1.2 and 1.4 were divided in two groups with the s.u. of block A connected and the s.u. of blocks B and $\mathrm{C}$ grouped, due to the proximity of these stretches in relation to stretch $\mathrm{A}$.

\section{Discussion}

From the cluster analysis, the dendrogram seemed a similarity in the abundance of macroinvertebrates s.u. of block A and blocks B and C similar to each other, with the stretches of block A presenting higher abundances than the other blocks. It showed the same pattern of grouping in relation to abiotic parameters, because the block A exhibited the highest values of eletrical conductivity and turbidity and lower dissolved oxygen values. This cluster was expected due to the proximity of the blocks $B$ and $\mathrm{C}$ which are physically separated from the block $\mathrm{A}$.

The cluster of s.u. from different stretch occurs due to structural characteristics (mesoscale variables) have more influence on the distribution and community composition than limnological parameters. Moreover, the macroscale variables are hierarchically higher than mesoscale (Vilella et al., 2004).

The aggregated distribution of benthic macroinvertebrates may result in a dominance of some groups with a great diversity of species (Bicudo and Bicudo, 2007; Kumar and Khan, 2013; Negi and Mamgain, 2013). The dominance pattern of macroinvertebrates found in this study is commonly observed in others studies, which the class Insecta has a higher frequency and the family Chironomidae with greater abundance (Giuliatti and Carvalho, 2009; Silva and Henry, 2013).

First order streams have a great offer of allochthonous material and consequently a higher quantity of shredders and collectors organisms (Vannote et al., 1980). Because this, Chironomidae is often dominant in samples taken in lotic or lentic local, due to its tolerance to adverse conditions such as hypoxia and its higher competitive ability (Carvalho and Uieda, 2004; Marques et al., 1999).

The diverse food habit of Chironomid midges is common to the group. They are most collectorgatherers and predators, but we can find some large with shredders and scrapers habit. Chironomi and Tanypodini are the most frequent Chironomid tribes, last one are obligatory predators (Abílio et al., 2007; Giuliatti and Carvalho, 2009; Nin et al., 2009; Ribeiro and Uieda, 2005).

Ostracoda is a detritivore/herbivore group and most organisms are shredders, they are commonly found on the soft sediments at lentic habitats and they can support determined conditions, such as 

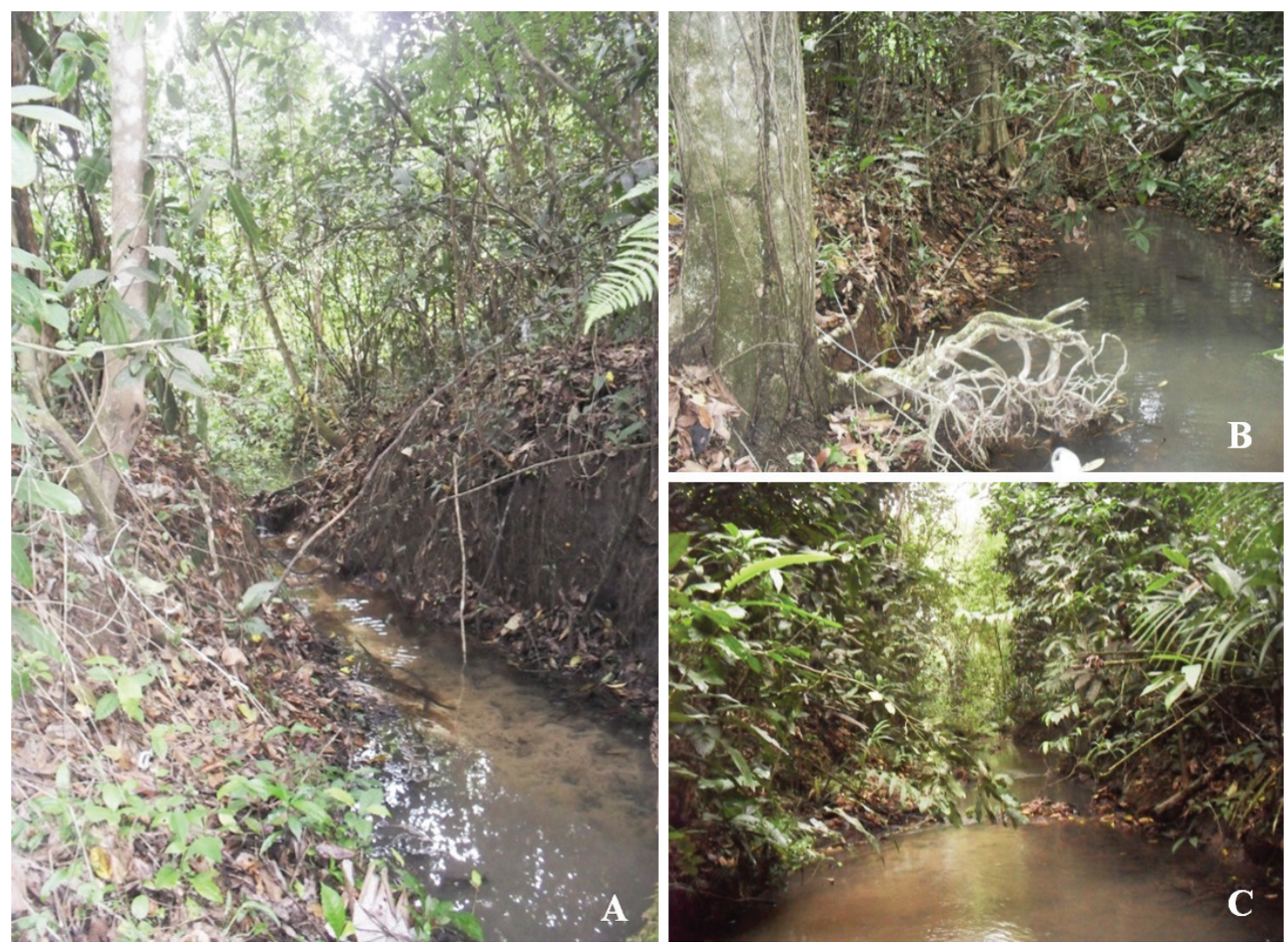

Figure 1. Images of the three blocks A, B and C, respectively, sampled during rainy season in May, 2013 at the stream Saltinho of the Biological Reserve of Saltinho, Tamandare city - Pernambuco, Brazil.

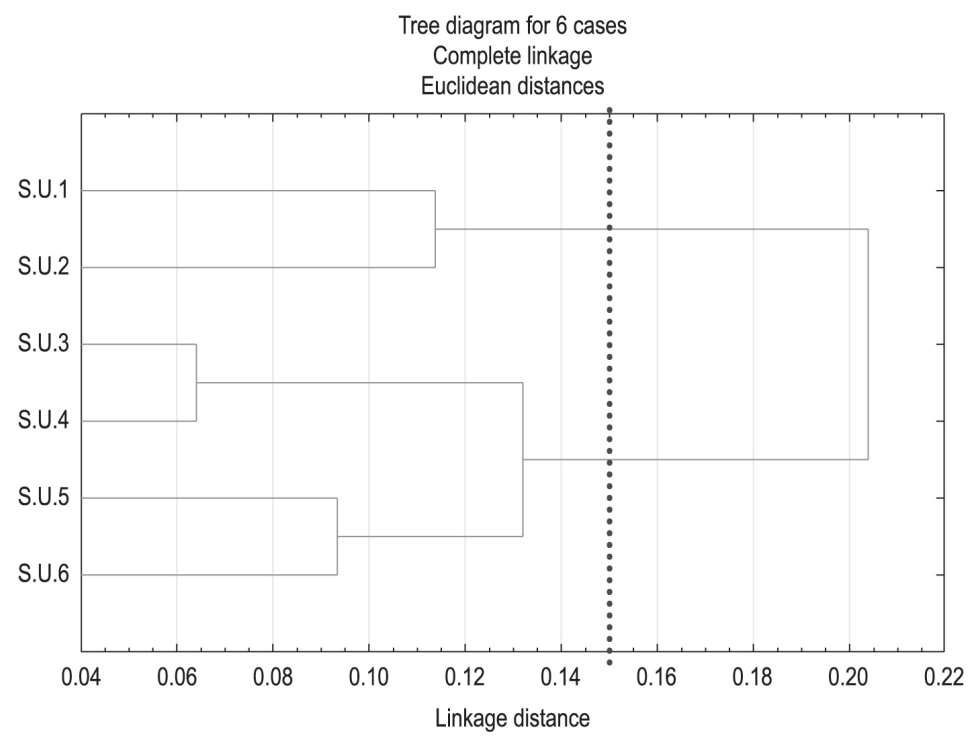

Figure 2. Dendrogram of cluster analysis based on six abiotic variables ( $\mathrm{pH}$-value, water temperature, electrical conductivity, turbidity, salinity and dissolved oxygen), macroinvertebrates abundance and richness in six sampling units (s.u.).

salinity, temperature and acidity (Gooderham and Tsyrlin, 2002; Iglikowska and Namiotko, 2012).

The most organisms of Coleoptera are predators with a wide ecological valence (Benetti and Hamada, 2003). Because of their adaptations to survive in aquatic habitat, they can live in aquatic and semiaquatic ecosystems, including lentic and lotic systems (Benetti and Régil Cueto, 2004). The families Hydrophilidae, Dytiscidae, Noteridae, Gyrinidae and Elmidae are the most found in 


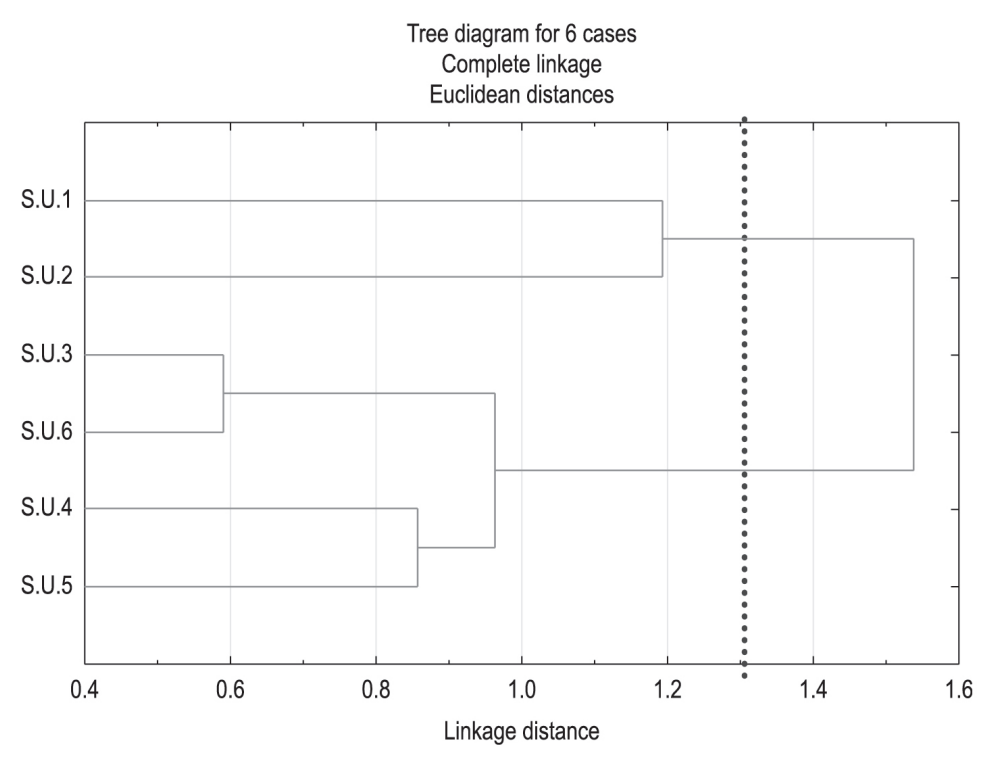

Figure 3. Dendrogram of cluster analysis based on six abiotic variables ( $\mathrm{pH}$-value, water temperature, electrical conductivity, turbidity, salinity and dissolved oxygen) and the eleven taxa of macroinvertebrates sampled in six sampling units (s.u.).

freshwater bodies at Atlantic forest of Pernambuco (Cunha, in prep.).

Among the limnological parameters evaluated those that influenced on the distribution and abundance of macroinvertebrates were: electrical conductivity, dissolved oxygen and turbidity. However, only the electrical conductivity significantly correlated with abundance, as found in previous works on first order streams, indicating the importance of this parameter as the structuring of macroinvertebrates assemblages (Baptista et al., 2001; Melo, 2009).

The electrical conductivity is connected with the variation of rainfall during the year. Indicating seasonal variations and the geological basis of geographical basin in which the water body is located, it can influence the composition and abundance of benthic fauna (Abílio et al., 2007). The lower values of electrical conductivity indicated that there is a lower concentration of dissolved ions and a smaller amount of external organic matter, which may be a parameter that contributes to the recognition of environmental impacts (Giuliatti and Carvalho, 2009). Also this parameter influenced the abundance of Ostracoda and Trichoptera, because EC had a role in the macroinvertebrates distribution (Rossaro et al., 2007). Despite the possible character indicative of pollution can be found tolerant individuals that have positive correlation with electrical conductivity and turbidity, such as ostracodes (Fulan et al., 2009).
The turbidity increases with the amount of dissolved solutes entered by the input of organic matter and allochthonous origin, exerting influence on the macroinvertebrate community (Abílio et al., 2007). The modification in abundance of Trichoptera and Ostracoda related to turbidity can be for the fact of macroinvertebrates diets be influenced by changes in resource availability due to turbidity-driven and variability in these diets can happen because of river turbidity (Kelly et al., 2013).

The rate of dissolved oxygen is characterized to be one of the limnological parameter that presents higher daily fluctuations. Its concentration is directly related to the processes of photosynthesis and respiration and/or decomposition that are associated with the light intensity and temperature. Besides, this parameter influences the metabolism of aquatic communities such as primary productivity, respiration and reproduction of organisms and decomposition of organic matter, which can also be induced by macroinvertebrates (Esteves, 2011).

The concentration of dissolved oxygen have daily and seasonal variations with higher concentrations during higher light incidence (Fulan et al., 2009), and the samples were collected at the rainy season that differ of the dry season because has less luminosity. It is consider one of the most important factors in macroinvertebrates distribution, which in several condition of organic pollution the concentration of dissolved oxygen is a limiting factor to species survival and more determinant in 
the community composition than food availability (Rossaro et al., 2007).

The negative linear correlation between Hemiptera and dissolved oxygen is explained because of the ability that they have to use the atmosphere oxygen; hence they can survive in bodies' water with lower levels of oxygen (Bouchard, 2004). The most ostracodes are found in habitats with low oxygen level and intermediate water temperatures with dissolved oxygen being one of the most influential parameters (Külköylüoğlu, 2003, 2005; Fernandes Martins et al., 2010). While the caddisflies are sensitive organisms that prefer cleaner aquatic habitats with low electrical conductivity and turbidity, in addition to well oxygenated (Bispo et al., 2006). The occurrence of organisms of the order Trichoptera may indicate a low organic enrichment of associated environments with this fauna. Because they are sensitive insects to organic pollution and characteristic of mesooligotrophic systems, that disappear under increasing eutrophication (Merritt and Cummins, 1984; Abílio et al., 2007).

Our hypothesis was accepted but limnological studies for tropical systems involving differentiated scales in respect of abiotic factors and macroinvertebrates community are still incipient. Then, more works that include parameters with different scales are still necessary, for the purpose to provide better grants to assess and monitor the quality of aquatic ecosystems.

The most predominant groups in this study (Chironomidae, Ostracoda and Coleoptera) presented detritivore and predator habits with variation in the abundance because of structural and limnological parameters. In Pernambuco state we cannot find macroinvertebrates studies in streams with this approach. The Atlantic forest of Pernambuco stay covered by sugar cane and rests some little fragments of native forest, because it is important studies that provide material for the monitoring of these areas. This study looked for to show a first record of macroinvertebrates community and physical and chemical parameter of water in an area of Altantic forest of Pernambuco.

\section{Acknowledgements}

The authors are thankful to colleagues for the assistance in field and laboratory work andJosias Cunha for the logistic effort at field. To CNPq and CAPES for the scholarship. To REBIO Saltinho for the support.

\section{References}

ABÍliO, FJP., RUFFO, TLM., SOUZA, AHFF, FLORENTINO, HS., OLIVEIRA JUNIOR, ET., MEIRELES, BNO. and SANTANA, ACD. 2007. Macroinvertebrados bentônicos como bioindicadores de qualidade ambiental de corpos aquáticos da caatinga. Oecologia Brasiliense, vol. 11, no. 3, p. $397-$ 409. http://dx.doi.org/10.4257/oeco.2007.1103.09

BAPTISTA, DF., DORVILLÉ, LF., BUSS, DF. and NESSIMIAN, JL. 2001. Spatial and temporal organization of aquatic insects assemblages in the longitudinal gradient of a tropical river. Revista Brasileira de Biologia, vol. 61, no. 2, p. 295-304. http:// dx.doi.org/10.1590/S0034-71082001000200012

BARBOLA, IF., MORAES, MFPG., ANAZAWA, TM., NASCIMENTO, EA., SEPKA, ER., POLEGATTO, CM., MillÉO, J. and SCHÜHLI, GS. 2011. Avaliação da comunidade de macroinvertebrados aquáticos como ferramenta para o monitoramento de um reservatório na bacia do Rio Pitangui, Paraná, Brasil. Iheringia. Série Zoologia, vol. 101, no. 1-2, p. 15-23.

BENETTI, CJ. and HAMADA, NO. 2003. Fauna de coleópteros aquáticos (insecta: coleoptera) na Amazônia central, Brasil. Acta Amazonica, vol. 33, no. 4, p. 701-709. http://dx.doi.org/10.1590/S004459672003000400015

BENETTI, CJ. and RÉGIL CUETO, JA. 2004. Fauna composition of water beetles (Coleoptera: Adephaga) in seven water environments in the municipality of Gramado, RS, Brazil. Acta Limnologica Brasiliensia, vol. 16 , no. 1 , p. 1-11.

BICUDO, CEM. and BICUDO, DC. 2007. Amostragem em limnologia. São Carlos: Rima. 351 p.

BISPO, PC., OLIVEIRA, LG., BINI, LM. and SOUSA, KG. 2006. Ephemeroptera, Plecoptera and Trichoptera assemblages from riffles in mountain streams of Central Brazil: environmental factors influencing the distribution and abundance of immatures. Brazilian Journal of Biolgy, vol. 66, no. 2b, p. 611-622. PMid:16906293. http://dx.doi. org/10.1590/S1519-69842006000400005

BOUCHARD, RW. 2004. Guide to aquatic invertebrates of the Upper Midwest: identification manual for students, citizen monitors, and aquatic resource professionals. St. Paul: University of Minnesota/ Water Research Center. 208 p.

Brasil. Ministério do Meio Ambiente - MMA. Instituto Brasileiro do Meio Ambiente e dos Recursos Naturais Renováveis - IBAMA. Plano de manejo: Reserva Biológica Saltinho. 2003. Brasília: MMA/IBAMA.

CARVALHO, EM. and UIEDA, VS. 2004. Colonização por macroinvertebrados bentônicos em substrato artificial e natural em um riacho da serra de Itatinga, São Paulo, Brasil. Revista Brasileira de Zoologia, vol. 21, no.2, p. 45-51. 
COSTA, C., IDE, S. and SIMONKA, CE. 2006. Insetos imaturos: metamorfose e identificação. Ribeirão Preto: Holos. 249 p.

CUNHA, JCS. Levantamento da coleopterofauna (Insecta) aquática em Unidades de Conservação da Floresta Atlântica, Pernambuco, Brasil. Recife: Universidade Federal de Pernambuco. In prep. [Dissertação de Mestrado em Biologia Animal].

ESTEVES, FA. 2011. Fundamentos de limnologia. Rio de Janeiro: Interciência. 226 p.

FERNANDES MARTINS, MJ., NAMIOTKO, T., CABRAL, MC., FATELA, F. and BOAVIDA, MJ. 2010. Contribution to the knowledge of the freshwater Ostracoda fauna in continental Portugal, with an updated checklist of Recent and Quaternary species. Journal of Limnology, vol. 69, no. 1, p. 160-173.

FERNÁNDEZ, HR. and DOMINGUES, E. 2001. Guia para la determinación de los artrópodos bentônicos sudamericanos. Tucumán: Universidad Nacional de Tucumán. 282p.

FRISSELL, CA., LISS, WJ., WARREN, C.E. and HURLEY, MD. 1986. A hierarchical framework for stream habitat classification: viewing streams in a watershed context. Environmental Management, vol. 10, no. 2, p. 199-214. http://dx.doi.org/10.1007/ BF01867358

FULAN, JA., DAVANSO, RCS. and HENRY, R. 2009. A variação nictemeral das variáveis físicas e químicas da água influencia a abundância dos macroinvertebrados aquáticos? Revista Brasileira de Biociências, vol. 7 , no. 2, p. 150-154.

GIULIATTI, TL. and CARVALHO, EM. 2009. Distribuição das assembleias de macroinvertebrados bentônicos em dois trechos do Córrego Laranja Doce, Dourados/MS. Interbio, vol. 3, no. 1, p. 4-14.

GOODERHAM, J. andTSYRLIN, E. 2002. The waterbug book: a guide to the freshwater macroinvertebrates of temperate Australia. Australia: CSIRO. 240 p.

GOULART, MDC. and CALLISTO, M. 2003. Bioindicadores de qualidade de água como ferramenta em estudos de impacto ambiental. Revista da FAPAM, ano 2, no. 1, p. 153-164.

HOLT, EA. and MILLER, SW. 2010. Bioindicators: using organisms to measure environmental impacts. Nature Education Knowledge, vol. 3, no. 10, p. 8.

IGLIKOWSKA, A. and NAMIOTKO, T. 2012. The impact of environmental factors on diversity of Ostracoda in freshwater habitats of subarctic and temperate Europe. Annales Zoologici Fennici, vol. 49, no. 4, p. 193-218. http://dx.doi. org/10.5735/086.049.0401

KELLY, HAW., ROSI-MARSHALL, EM., KENNEDY, TA., HALL, RO., CROSS, WF. and BAXTER, CV. 2013. Macroinvertebrate diets reflect tributary inputs and turbidity-driven changes in food availability in the Colorado River downstream of Glen Canyon Dam. Freshwater Science, vol. 32, no. 2, p. 397-410. http://dx.doi.org/10.1899/12-088.1

KIKUCHI, RM. and UIEDA, VS. 1998. Composição da comunidade de invertebrados de um ambiente lótico tropical e sua variação espacial e temporal. In NESSIMIAN, JL. and CARVALHO, AL., eds. Ecologia de insetos aquáticos. Séries Oecologia Brasiliensis, vol. 5. Rio de Janeiro: PPGE/UFRJ. p. 157-173.

KUBÍKOVÁ, L., SIMON, OP., TICHÁ, K., DOUDA, K., MACIAK, M., and BÍLÝ, M. 2012. The influence of mesoscale habitat conditions on the macroinvertebrate composition of springs in a geologically homogeneous area. Freshwater Science, vol. 31, no. 2, p. 668-679. http://dx.doi. org/10.1899/11-174.1

KÜLKÖYLÜOĞLU, O. 2003. Ecology of freshwater Ostracoda (Crustacea) from lakes and reservoirs in Bolu, Turkey. Journal of Freshwater Ecology, vol. 18, no. 3, p. 343-347. http://dx.doi.org/10.1080/0270 5060.2003.9663968

KÜLKÖYLÜOĞLU, O. 2005. Ecological requirements of freshwater Ostracoda (Crustacea) in two limnocrene springs (Bolu, Turkey). Annales de Limnologie - International Journal of Limnology, vol. 41, no. 4, p. 237-246. http://dx.doi.org/10.1051/ $\operatorname{limn} / 2005016$

KUMAR, PS. and KHAN, AB. 2013. The distribution and diversity of benthic macroinvertebrate fauna in Pondicherry mangroves, India. Aquatic Biosystems, vol. 9, no. 1, p. 15. PMid:23937801 PMCid:PMC3751066. http://dx.doi. org/10.1186/2046-9063-9-15

MARQUES, MGS., FERREIRA, RL. and BARBOSA, FAR. 1999. A comunidade de macroinvertebrados aquáticos e características limnológicas das lagoas Carioca e da Barra, Parque Estadual do Rio Doce, MG. Revista Brasileira de Biologia, vol. 59, no. 2, p. 203-210. http://dx.doi.org/10.1590/S003471081999000200004

MELO, AS. 2009. Explaining dissimilarities in macroinvertebrate assemblages among stream sites using environmental variables. Zoologia, vol. 26, no. 1, p. 79-84.

MERRITT, RW. and CUMMINS, KW. 1984. An introduction to the aquatic insects of North America. 2nd ed. Dubuque: Kendall/Hunt Publishing Company. $722 \mathrm{p}$.

MUGNAI, R., NESSIMIAN, JL. and BAPTISTA, DF. 2010. Manual de identificação de macroinvertebrados aquáticos do Estado do Rio de Janeiro: para atividades técnicas, de ensino e treinamento em programas de avaliaçáo da qualidade ecológica dos ecossistemas lóticos. Rio de Janeiro: Techinal Books. 176 p. 
NEGI, RK. and MAMGAIN, S. 2013. Seasonal variation of benthic macro invertebrates from Tons River of Garhwal Himalaya Uttarakhand. Pakistan Journal of Biological Sciences, vol. 16, no. 22, p. 1510-1516. PMid:24511693. http://dx.doi.org/10.3923/ pjbs.2013.1510.1516

NIN, CS., RUPPENTHAL, EL. and RODRIGUES, GG. 2009. Produção de folhiço e fauna associada de macroinvertebrados aquáticos em curso d'água de cabeceira em Floresta Ombrófila do Estado do Rio Grande do Sul, Brasil. Acta Scientiarum. Biological Sciences, vol. 31, no. 3, 2009, p. 263-271.

RIBEIRO, LO. and UIEDA, VS. 2005. Estrutura da comunidade de macroinvertebrados bentônicos de um riacho de serra em Itatinga, São Paulo, Brasil. Revista Brasileira de Zoologia, vol. 22, no.3, p. 613-618. http://dx.doi.org/10.1590/S010181752005000300013

ROSENBERG, DM. and RESH, VH. 1993. Freshwater biomonitoring and benthic macroinvertebrate. New York: Chapman \& Hall. 488 p.

ROSSARO, B., MARZIALI, L., CARDOSO, AC., SOLIMINI, A., FREE, G. and GIACCHINI, R. 2007. A biotic index using benthic macroinvertebrates for Italian lakes. Ecological
Indicators, vol. 7, no. 2, p. 412-429. http://dx.doi. org/10.1016/j.ecolind.2006.04.002

SILVA, CV. and HENRY, R. 2013. Aquatic macroinvertebrates associated with Eichhornia azurea (Swartz) Kunth and relationships with abiotic factors in marginal lentic ecosystems (São Paulo, Brazil). Brazilian Journal of Biology, vol. 73, no. 1, p. 149162. PMid:23644797. http://dx.doi.org/10.1590/ S1519-69842013000100016

VANNOTE, RL., MINSHALL, GW., CUMMINS, KW., SEDELL, JR. and CUSHING, CE. 1980. The river continuum concept. Canadian Journal of Fisheries and Aquatic Sciences, vol. 37, p. 130-137. http://dx.doi.org/10.1139/f80-017

VILELLA, FS., BECKER, FG., HARTZ, SM. and BARBIERI, G. 2004. Relation between environmental variables and aquatic megafauna in a first order stream of the Atlantic Forest, southern Brazil. Hydrobiologia, vol. 528, p. 17-30. http:// dx.doi.org/10.1007/s10750-004-0688-6

WU, J. and LOUCKS, OL. 1995. From balance of nature to hierarchical patch dynamics: a paradigm shift in ecology. The Quarterly Review of Biology, vol. 70, no. 4, p. 439-466. http://dx.doi.org/10.1086/419172

Received: 20 August 2013 Accepted: 12 May 2014 